\title{
p53 Expression during Normal Tissue Regeneration in Response to Acute Cutaneous Injury in Swine
}

\author{
Harry N. Antoniades, „‡ Theofanis Galanopoulos, ${ }^{\star}$ Janine Neville-Golden, “ Christopher P. Kiritsy" and Samuel E. Lynch ${ }^{81}$ \\ *The Center for Blood Research; ${ }^{\ddagger}$ Departments of Cancer Biology and Nutrition, Harvard School of Public Health; ${ }^{\S}$ Department of \\ Periodontology, Harvard School of Dental Medicine, Boston, Massachusetts 02115; and "Institute of Molecular Biology, \\ Worcester, Massachusetts 01605
}

\begin{abstract}
The present studies investigated the in vivo expression of the p53 suppressor gene and protein product in response to acute cutaneous injury in swine, along with the parallel expression of the c-sis/PDGF-B mitogen and its receptor $\beta$ (PDGF-R $\beta$ ). p53 expression was shown to be suppressed during the period of active cellular proliferation in the injured tissue and to reemerge during the stages of healing. In contrast, c-sis/PDGF-B and PDGF-R $\beta$ were expressed during the early phase of active cellular proliferation and they were suppressed upon healing. This inverse relationship between mitogenic growth factors and p53 suggests the presence of well-controlled physiologic mechanisms that regulate in vivo the processes of normal tissue repair in response to injury. At the stages of tissue regeneration, these mechanisms include both the expression of growth factors that promote cell proliferation and the suppression of p53 that downregulates proliferation. At the stages of healing, the expression of the mitogenic growth factors is suppressed and that of p53 reemerges, reaching its peak at the time of complete epithelialization and healing of the injured tissue. These studies are the first to link the response of p53 protein to physiologic processes of tissue regeneration in vivo. (J. Clin. Invest. 1994. 93:2206-2214.) Key words: suppressor genes - growth factors $\cdot \mathrm{p53} \cdot$ tissue regeneration · gene induction
\end{abstract}

\section{Introduction}

In vivo studies suggest that normal tissue regeneration after injury is mediated by the localized expression of several mitogenic growth factors and growth factor receptors at the site of injury (1-12). This localized expression of mitogenic growth factors and their receptors after injury seems to contribute to the complex processes involved in tissue regeneration. The expression levels induced by cutaneous injury were shown to be maximal during the stages of active tissue repair, declining and suppressed upon the healing of the wound $(10,12)$. This controlled reversible expression of growth factors and their receptors in response to injury suggests that molecular mechanisms can be activated at the cellular level that contribute to the in-

Address correspondence and reprint requests to Prof. Harry N. Antoniades, Institute of Molecular Biology, One Innovation Drive, Worcester, MA 01605-4308.

Received for publication 24 September 1993 and in revised form 30 December 1993.

1. Abbreviation used in this paper: PDGF-R $\beta$, PDGF receptor $\beta$.

J. Clin. Invest.

(C) The American Society for Clinical Investigation, Inc.

0021-9738/94/05/2206/09 \$2.00

Volume 93, May 1994, 2206-2214 duction of gene expression in response to cellular injury, and the suppression of these genes upon healing.

In the present studies, we have investigated the expression of $\mathrm{p} 53 \mathrm{mRNA}$ and its protein product in skin biopsy specimens from healthy swine before and after acute cutaneous injury. P53 expression seen in these studies represents the wild-type form present in normal, non-malignant tissue. The p53 mRNA and protein expression in the biopsy specimens was compared with the parallel expression, in the same specimens, of a mitogenic growth factor, the PDGF-B (c-sis/PDGF-B) mRNA and its receptor $\beta$ (PDGF-R $\beta)^{1}$ mRNA and their respective protein products (for a review on PDGF, see reference 13). The p53 gene is located in the short arm of human chromosome 17, and it encodes a 393-amino acid nuclear phosphoprotein (14). The wild type p53 protein is a tumor suppressor, and this function results from its ability to arrest cell cycle progression (15-21). This effect of wild type p53 on the cell cycle appears to be mediated by transcriptional transactivation (22-30) and transcriptional suppression (31-35) of genes that are involved in the control of cellular growth (for recent reviews, see references 36-38). A role of p53 in DNA repair has been reported $(39,40)$.

Because of these functional roles, we have investigated the response of $\mathrm{p} 53$ to cellular injury in vivo to examine the following: a possible correlation between the levels of $\mathrm{p} 53$ expression and the proliferative state that characterizes normal tissue repair after injury; and a possible correlation between p53 expression and the expression of mitogenic growth factors and receptors (PDGF-B, PDGF-R $\beta$ ) in response to injury and their suppression in response to healing.

In the present investigations, mRNA and protein expression was established using in situ hybridization and immunohistochemistry, respectively. These techniques allow not only demonstration of expression but they also enable the cellular localization of the expression. This permits a direct comparison of the expression of p53 in a given cell type with that of mitogenic growth factor genes and their receptors.

\section{Methods}

Collection of skin biopsy specimens. Partial thickness wounds $(10 \times 15$ $\mathrm{mm}$ ) were surgically induced in the back of young white Yorkshire pigs $(10-15 \mathrm{~kg})$ at a depth of $1.00 \mathrm{~mm}$ using a modified Castroviejo electrokeratome (Storz, St. Louis, MO; modified by Brownells, Montezuma, IA). Total excisional skin biopsy specimens were obtained from normal, uninjured skin before wounding (control), and at 1,3 , and $6 \mathrm{~h}$ after wounding, and then daily for $5 \mathrm{~d}$, and at 9 and $17 \mathrm{~d}$ after wounding. In this model, epithelialization of the injured tissue occurred at $5 \mathrm{~d}(41)$. In Situ Hybridization. For in situ hybridization, sections (2-mm thick) from fresh biopsy specimens were immersed in ice-cold $4 \%$ paraformaldehyde for $2-8 \mathrm{~h}$ and allowed to sink in $30 \%$ sucrose/PBS overnight at $4^{\circ} \mathrm{C}$ to decrease freezing artifacts. The fixed tissues were then embed- 


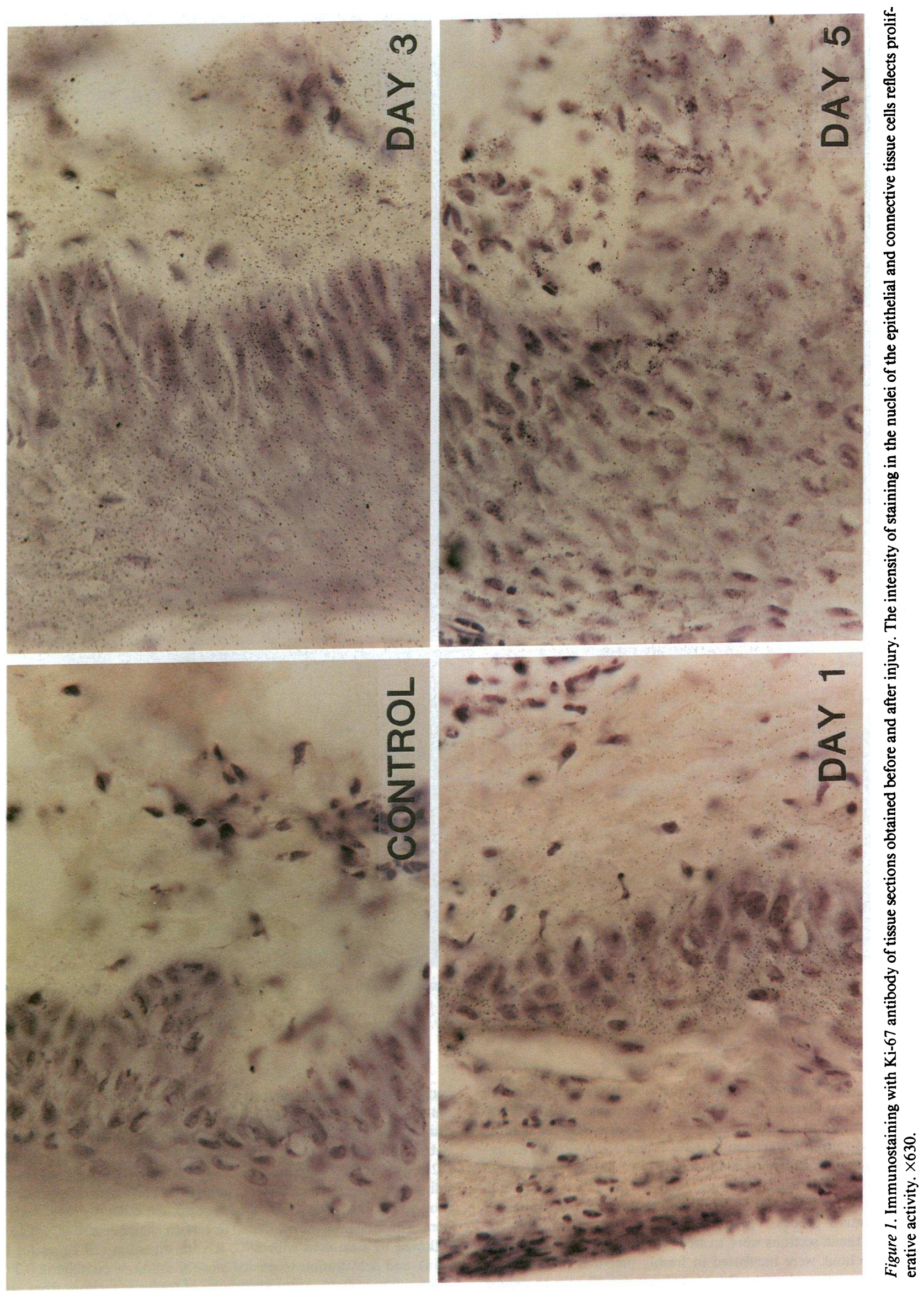



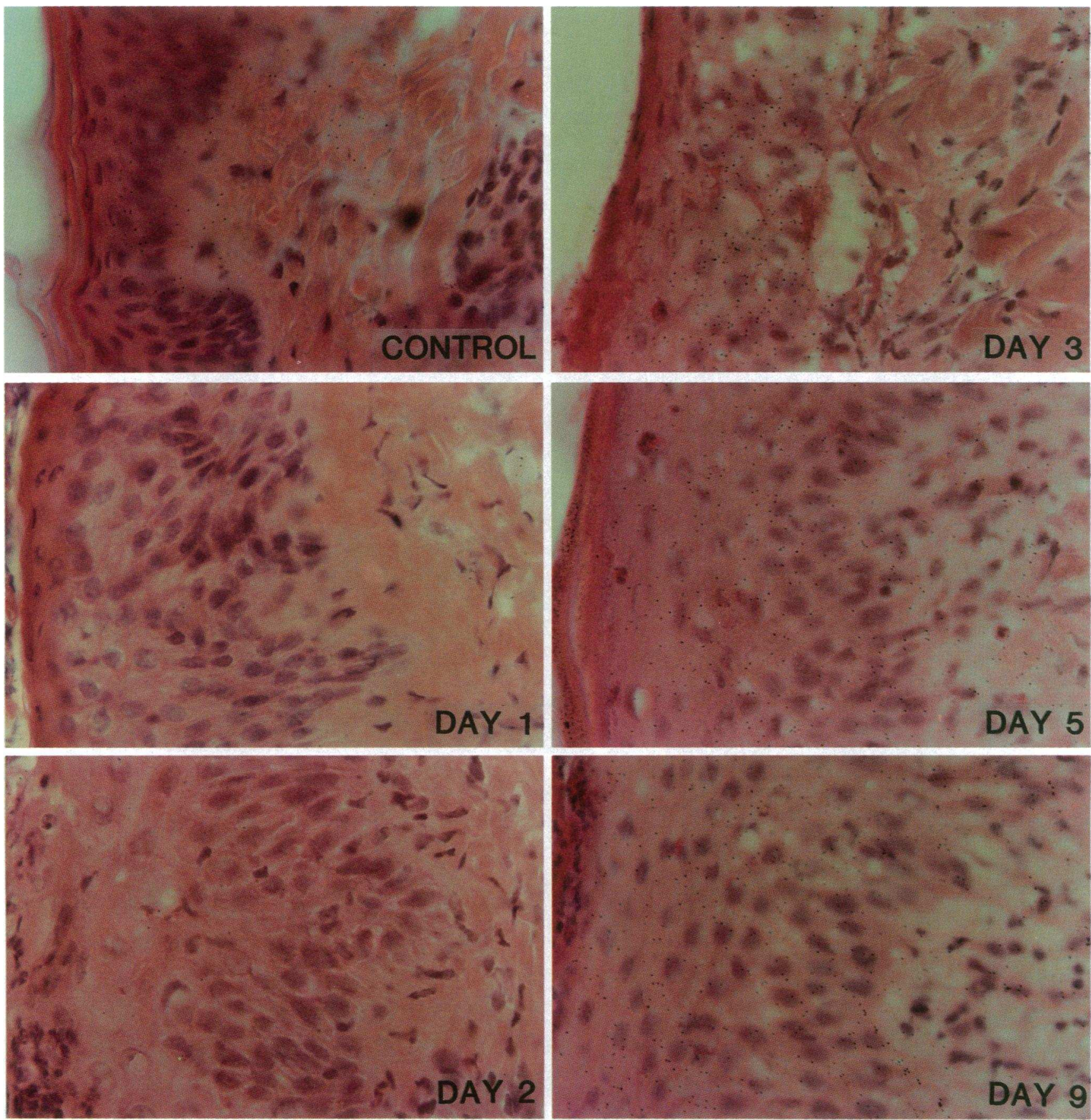

Figure 2. Expression of p53 mRNA in the skin epithelial and connective tissue cells before and after injury. Notice the absence of significant mRNA expression on days 1 and 2 after injury. $\times 630$.

ded in OCT (Miles Laboratories, Inc., Naperville, IL) for cryostat serial sectioning $(8 \mu \mathrm{m})$. The sectioned tissues were rehydrated in PBS at room temperature and immersed in $0.1 \mathrm{M}$ glycine/PBS for $5 \mathrm{~min}$, followed by a 15 -min immersion in $0.3 \%$ Triton X-100/PBS. The tissues were washed in PBS and then incubated in $1 \mu \mathrm{g} / \mathrm{ml}$ Proteinase $\mathrm{K}$ (Sigma Immunochemicals, St. Louis, MO), $0.1 \mathrm{M}$ Tris, pH 8.0, and $0.05 \mathrm{M}$ EDTA, $\mathrm{pH} 8.0$, at $37^{\circ} \mathrm{C}$ for $30 \mathrm{~min}$ to improve penetration of the hybridization probes. To stop proteolysis and decrease loss of mRNA, the tissue sections were treated with $4 \%$ paraformaldehyde/ PBS. The sections were incubated in freshly prepared $0.25 \%$ acetic anhydride in triethanolamine, $0.1 \mathrm{M}, \mathrm{pH} 8.0$, for $10 \mathrm{~min}$ to reduce background in autoradiographs and then prehybridized in 50\% formamide $/ 2 \mathrm{X} \mathrm{SSC}$ at $42^{\circ} \mathrm{C}$ for $15 \mathrm{~min}$. After that, the tissue sections were drained and then received $10 \mu \mathrm{l}$ of hybridization mixture, containing hybridization buffer ( $50 \%$ formamide, $2 \mathrm{X}$ SSC, $10 \%$ dextran sulfate, $0.25 \%$ bovine serum albumin, $0.25 \%$ Ficoll $400,0.25 \%$ polyvinyl-pyrolidine $360,0.5 \%$ sodium dodecylsulfate, and $250 \mu \mathrm{g} / \mathrm{ml}$ denatured salmon sperm DNA) and the ${ }^{35}$ S-labeled antisense RNA probe, $3 \times 10^{5}$ $\mathrm{cpm}$. The sections were incubated in a moist chamber at $420 \mathrm{C}$ for $16 \mathrm{~h}$, followed by treatment with SSC, RNAse digestion $(20 \mu \mathrm{g} / \mathrm{ml}$ for 30 $\mathrm{min}$ ), and dehydration in graded alcohol solutions containing $0.3 \mathrm{M}$ ammonium acetate. Autoradiography of triplicate sections from each 

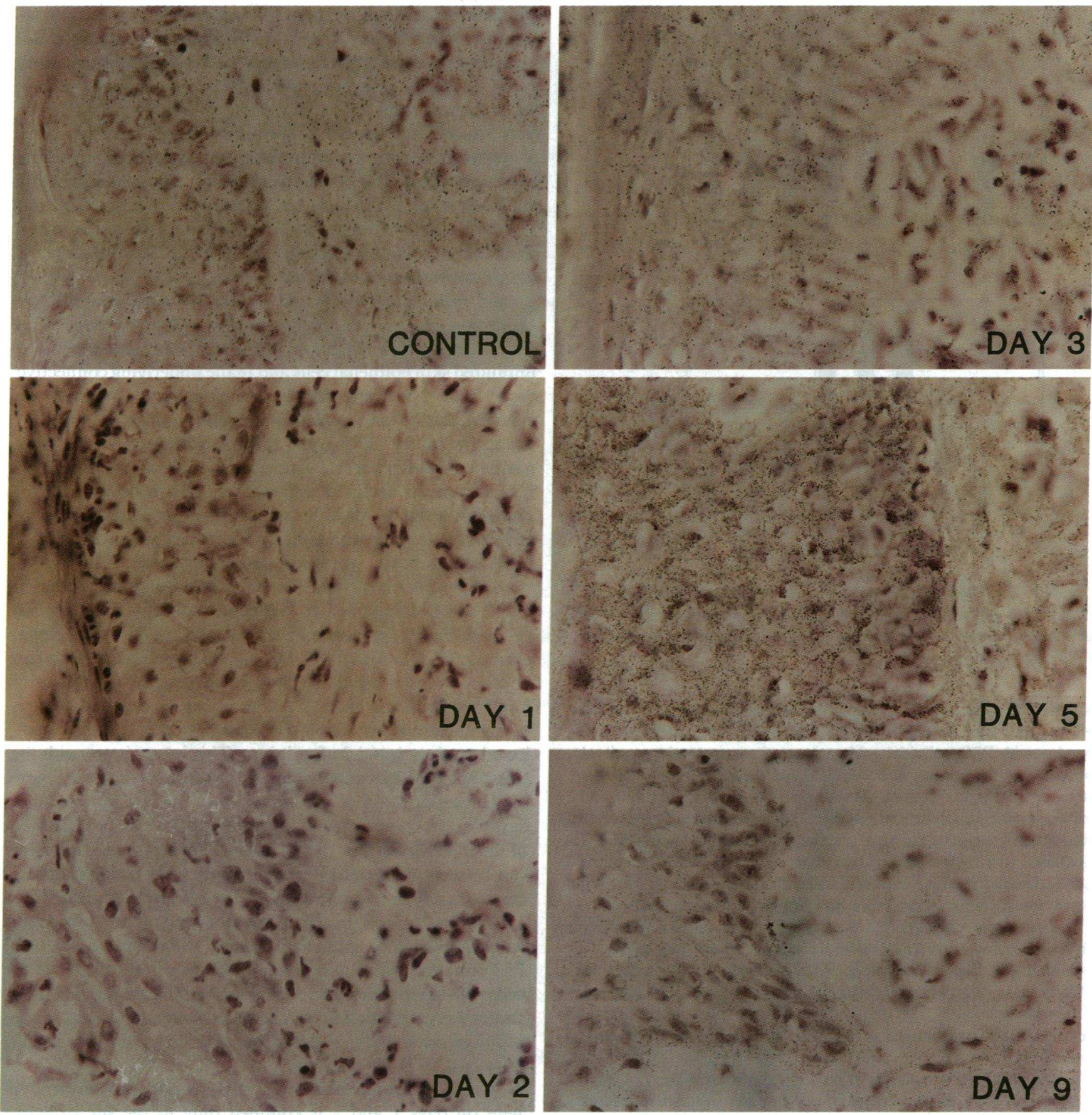

Figure 3. Expression of p53 protein in the skin epithelial and connective tissue cells before and after injury. Notice the absence of significant protein expression on days 1 and 2 after injury. $\times 630$.

tissue was performed using NTB2 (Eastman Kodak, Rochester, NY) and were developed and stained with hematoxylin and eosin at weekly intervals for $3 \mathrm{wk}$. Data presented here are from a 2-wk exposure. The specificity of the in situ hybridization was controlled by parallel hybridization of serial tissue sections with control, noncomplementary (sense) riboprobes.

The antisense RNA probes used in these studies were for human wild type p53 (42), human c-sis/PDGF-B (43), and mouse PDGF-R $\beta$ (44).

RNA probes were prepared as described in Höfler et al. (45) using the Gemini II system (Promega Corp., Madison, WI). To test the integrity of the probes, $1 \mu \mathrm{l}\left(2 \times 10^{6} \mathrm{cpm}\right)$ of the probe was run on a $5.5 \%$ formaldehyde reducing gel, transferred onto a nytran membrane, and washed in water. The membrane was then exposed to an x-ray film for $1-3 \mathrm{~h}$. The presence of a single transcript indicated that the probe was intact.

Immunocytochemistry. Protein expression in serial sections of the biopsy specimens were detected using the colloidal gold labeling technique (46). For this purpose, the tissue sections $(5 \mu \mathrm{m})$ were first incubated for $60 \mathrm{~min}$ at room temperature with specific primary antibodies to $\mathrm{p} 53(47,48)$ (mouse anti-wild type $\mathrm{p} 53$ monoclonal antibody, clone PAb-246, Oncogene Science, Manhasset, NY); to c-sis/PDGF-B (guinea pig antibody specific for PDGF-B, Institute of Molecular Biology, Inc., Worcester, MA); and to PDGF-R $\beta$ (guinea pig antibody to a 


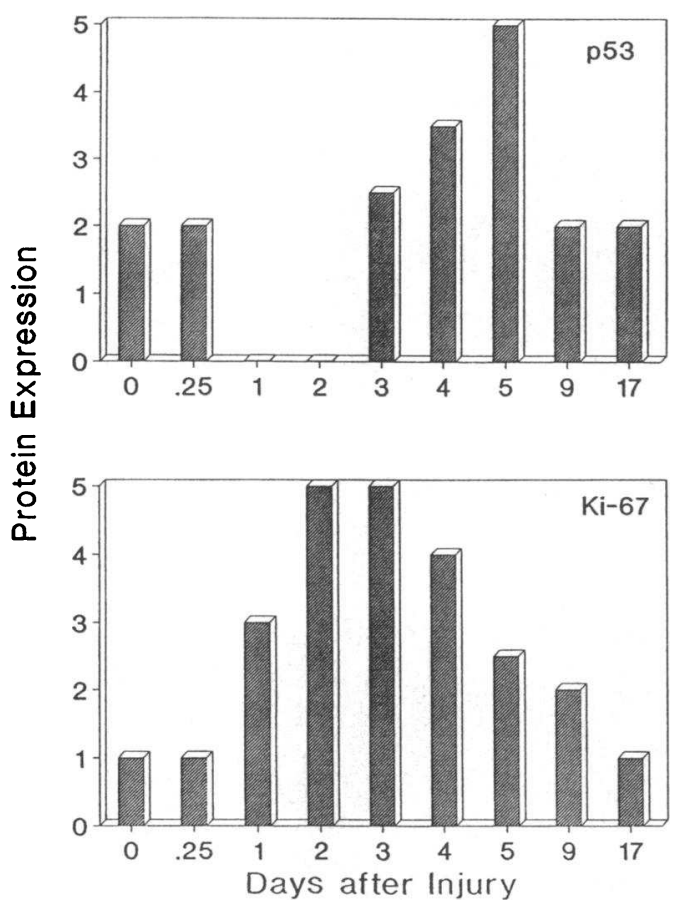

Figure 4. Expression of $\mathrm{p} 53$ and $\mathrm{Ki}-67$ proteins in the skin epithelial cells before and after injury. Notice the inverse relationship between p53 and $\mathrm{Ki}-67$ protein expression during the phase of active cellular proliferation (days 1-3).

synthetic peptide corresponding to the kinase polypeptide region 958980 of the sequence reported by Yarden et al. (44). After five 3-min washes with PBS, colloidal gold conjugated to a secondary antibody, recognizing the primary antibody, was applied for $30 \mathrm{~min}$ to the tissue sections. The tissue sections were washed with $\mathrm{H}_{2} \mathrm{O}$ several times, and a silver enhancing solution was applied. After washing with $\mathrm{H}_{2} \mathrm{O}$ several times, the tissue sections were counterstained with hematoxyline, dehydrated in ethanol, cleared in xylene, and mounted. The colloidal gold labeling technique used in these studies is considered to be 10 -fold more sensitive than those based on immunoperoxidase staining.

Assessment of proliferative activity. The proliferative activity in the biopsy specimens obtained before and after injury was assessed by staining with the mouse monoclonal antibody $\mathrm{Ki}-67$ (Amac, Inc., Westbrooke, MN) (49), using for this purpose the colloidal gold labeling technique (46). This antibody recognizes a nuclear cell proliferation-associated antigen in cells and it serves as a test of nuclear reactivity.

Quantitation of $m R N A$ and protein expression. Values of mRNA expression show the percentage of positive cells in the tissue sections. Mean values were obtained by counting the number of positive cells in $8-10$ consecutive fields. Positive expression is considered if three or more grains are present over the cell.

Protein product expression was estimated with an arbitrary scale of $1-5,5$ exhibiting the most intense staining.

\section{Results}

Proliferative activity in biopsy specimens. Immunostaining of normal, uninjured skin sections with the Ki-67 antibody shows a very light staining that is confined only in the basal epithelial layer (Fig. 1). There is no evidence for staining of the connective tissue cells. $6 \mathrm{~h}$ after injury, there is a light staining in the epithelial and connective tissue cells adjacent to the injured tissue. Strong immunostaining can be seen in both epithelial and connective tissue cells at the site of injury on days $1-3$, and this staining declined progressively on days 4-9, returning to preinjury levels by day 17 (Fig. 1). Epithelialization of the injured tissue in these studies is seen at $\sim 5 \mathrm{~d}$ after injury. As seen in Fig. 1, on day 5, there is a significant reduction in the staining of the epithelial region. However, we have noticed that on days 5 and 9, staining can be seen in the basal epithelial layers of epithelial extensions within the dermis, suggesting an active ongoing process of epithelial tissue remodeling. Staining with the $\mathrm{Ki}-67$ antibody is localized primarily in the nuclei of the cells with light staining present in the cytoplasm. Staining of serial tissue sections with control mouse IgG did not produce a significant expression (data not shown).

p53 mRNA expression. As shown in Fig. 2, p53 mRNA expression can be seen in the control, uninjured tissue. The mRNA expression is light, but it is uniformly present in the uninjured skin epithelial cells and in the underlying connective tissue cells. 1-6 $\mathrm{h}$ after injury, the expression remained unchanged, but it was completely suppressed on days 1 and 2 at the site of injury. Strong p53 mRNA expression can be seen again in the epithelial and connective tissue cells on day 3 , and this expression declined progressively, reaching the control preinjury levels by days 9 and 17. Control hybridization of serial tissue sections with noncomplimentary riboprobe did not produce significant expression (data not shown).

p53 protein expression. The p53 mRNA expression seen in Fig. 2 was accompanied by the expression of its p53 protein product (Fig. 3), as judged by the use of a specific monoclonal antibody (Pab-246) $(47,48)$. Strong $p 53$ protein expression can be seen in the epithelial and connective tissue cells of the uninjured control tissue and $\leq 6 \mathrm{~h}$ after injury. In contrast, there is no significant $\mathrm{p} 53$ protein expression in biopsy specimens collected on days 1 and 2 after injury. This is consistent with the lack of p53 mRNA expression on the same specimens (Figure 2). The suppression of p53 protein and mRNA expression in days 1 and 2 coincides with the state of active cell proliferation of the injured tissue as shown in Fig. 1.p53 protein expression can be seen again on day 3 after injury, with a significant increase on day 5 , and returning to control levels on days 9 and 17. The peak of $\mathrm{p} 53$ protein expression seen on day 5 coincides with the timing of epithelialization of the injured tissue (41). P53 protein expression is present primarily in the nuclei of the cells with some expression seen in the cytoplasm. Fig. 4 demonstrates the correlation between $\mathrm{p} 53$ protein expression and the proliferative activity of the epithelial cells at the site of injury, as judged by $\mathrm{Ki}-67$ staining.

The suppression of the p53 mRNA and protein product seen on days 1 and 2 is confined only to the site of active proliferation of the injured tissue. Distant areas of intact uninjured epithelial and connective tissue cells in the biopsy specimens continued to express p53 mRNA and protein levels similar to those seen in the uninjured control tissue shown in Figs. 2 and 3 (data not shown).

Expression of c-sis/PDGF-B and PDGF-R $\beta$ mRNAs and protein products. We compared the expression of p53 mRNA and its protein product to that of c-sis/PDGF-B and its receptor $\beta$ (PDGF-R $\beta$ ) in the same biopsy specimens. As shown in Fig. 5, there was no significant c-sis/PDGF-B or PDGF-R $\beta$ mRNA expression in the epithelial and connective tissue cells of the control, uninjured tissue. A strong expression of PDGF$\mathrm{R} \beta \mathrm{mRNA}$ can be seen within $6 \mathrm{~h}$ of injury. This expression increased progressively on days 1 and 2 , it declined on day 5 , and it was completely suppressed by day 9 after injury. 

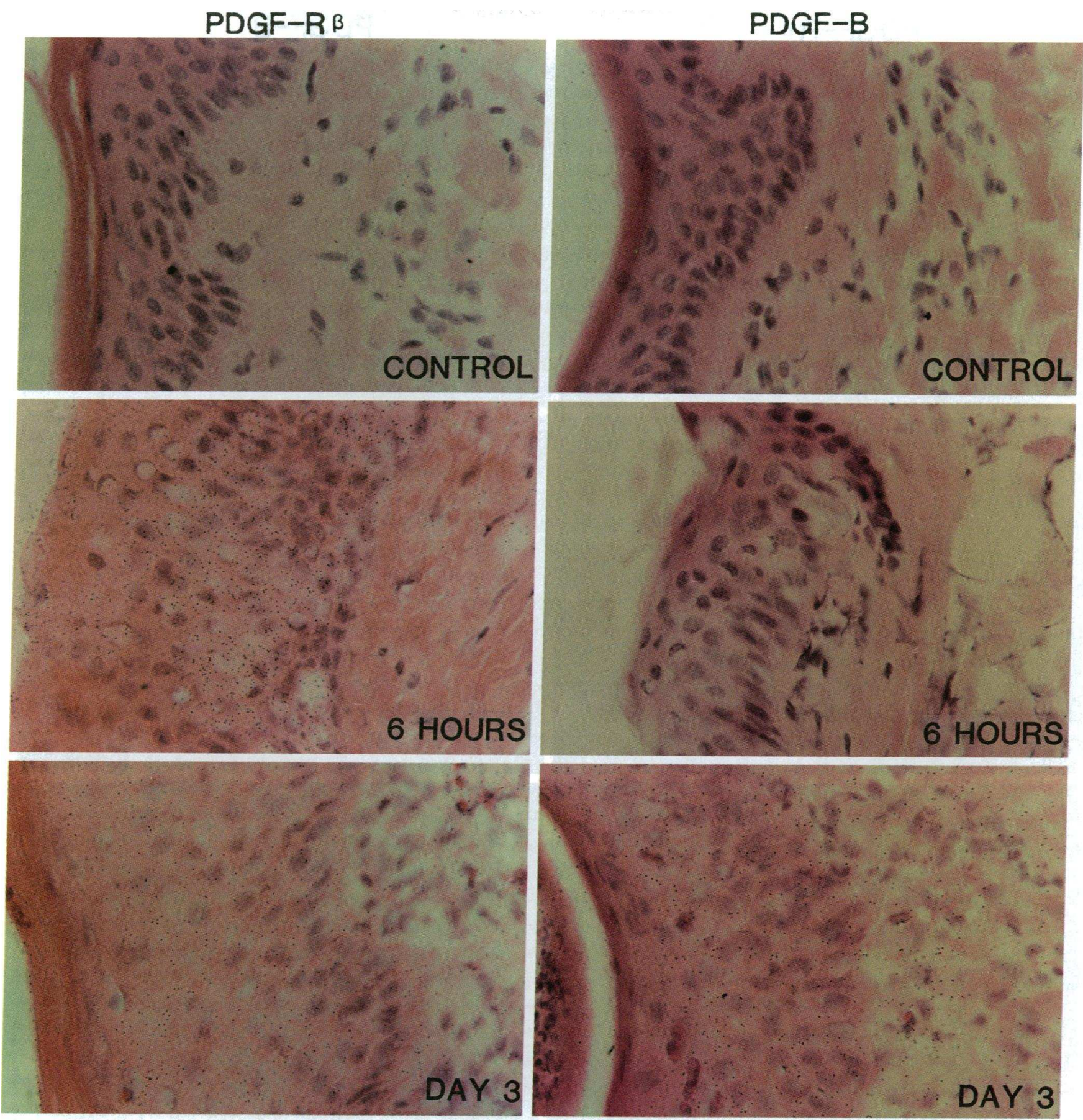

Figure 5. Examples of the expression of PDGF-R $\beta$ and c-sis/PDGF-B mRNAs before injury, and at $6 \mathrm{~h}$ and $3 \mathrm{~d}$ after injury. Notice the early strong expression of PDGF-R $\beta$ mRNA $6 \mathrm{~h}$ after injury and the absence of PDGF-B expression in the same tissue specimen. $\times 630$.

There was no significant expression of c-sis/PDGF-B mRNA in the control uninjured tissue and at $6 \mathrm{~h}$ after injury. Expression of c-sis/PDGF-B mRNA can be seen on day 1 after injury, it remained strong on days 2 and 3 , it declined progressively on days 5 and 9 , and it was totally suppressed by day 17 after injury.

The expression of the PDGF-R $\beta$ mRNA preceded that of the c-sis/PDGF-B, and it was suppressed earlier than c-sis/ PDGF-B. However, both the c-sis/PDGF-B and its receptor mRNAs were strongly expressed during the stages of active cellular proliferation of the injured tissue. Their expression was accompanied by the expression of their respective protein products as shown in the examples presented in Fig. 6.

The data described above suggest an inverse relationship between the expression of c-sis/PDGF-B and its receptor and that of $\mathrm{p} 53$ expression. This inverse relationship is evident in Fig. 7, which summarizes the findings. The data show the percentage of epithelial cells in the injured tissue that express the individual mRNAs before and at various intervals after acute cutaneous injury. Protein product expression in the epithelial cells is estimated with an arbitrary scale of 1-5. It is of interest to notice that in the case of $\mathrm{p} 53$, the intensity of protein expres- 

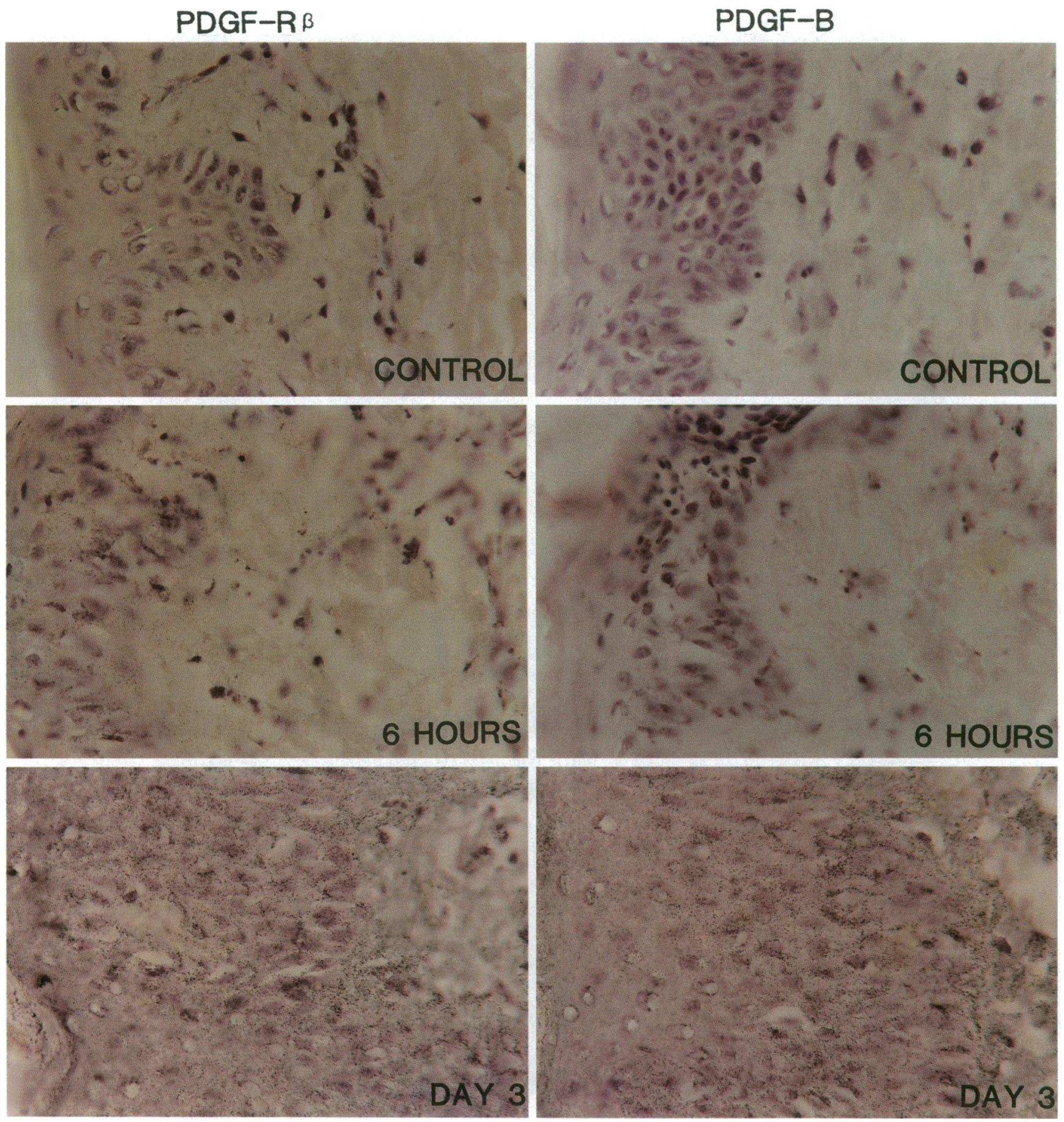

Figure 6. Examples of PDGF-R $\beta$ and c-sis/PDGF-B protein expression before injury and at $6 \mathrm{~h}$ and $3 \mathrm{~d}$ after injury. There is no significant expression of PDGF-B protein at $6 \mathrm{~h}$ after injury. $\times 630$.

sion does not parallel the intensity of its mRNA expression. For example, mRNA expression in the control specimen and at $6 \mathrm{~h}$ after injury is weak, but the protein expression is strong. Similarly, on day 3, mRNA intensity is higher than that seen on day 5 , but the reverse is seen with the protein product (Fig. 7).

\section{Discussion}

Normal tissue repair is characterized by an active proliferative state that contributes to the healing of the injured tissue. This proliferation process is stimulated by the localized expression of selective growth factors and receptors (1-12) that promote tissue regeneration. In the examples presented here, expression of PDGF-R $\beta$ occurred within $6 \mathrm{~h}$ of injury, and that of the PDGF-B mitogen within $1 \mathrm{~d}$ of injury. Their expression increased progressively during the phase of active cellular proliferation, and it was suppressed upon the healing of the injured tissue (Fig. 7). A similar response has been reported for other mitogenic growth factors such as TGF-a and its receptor, the EGF receptor, and acidic and basic fibroblast growth factors (12). 

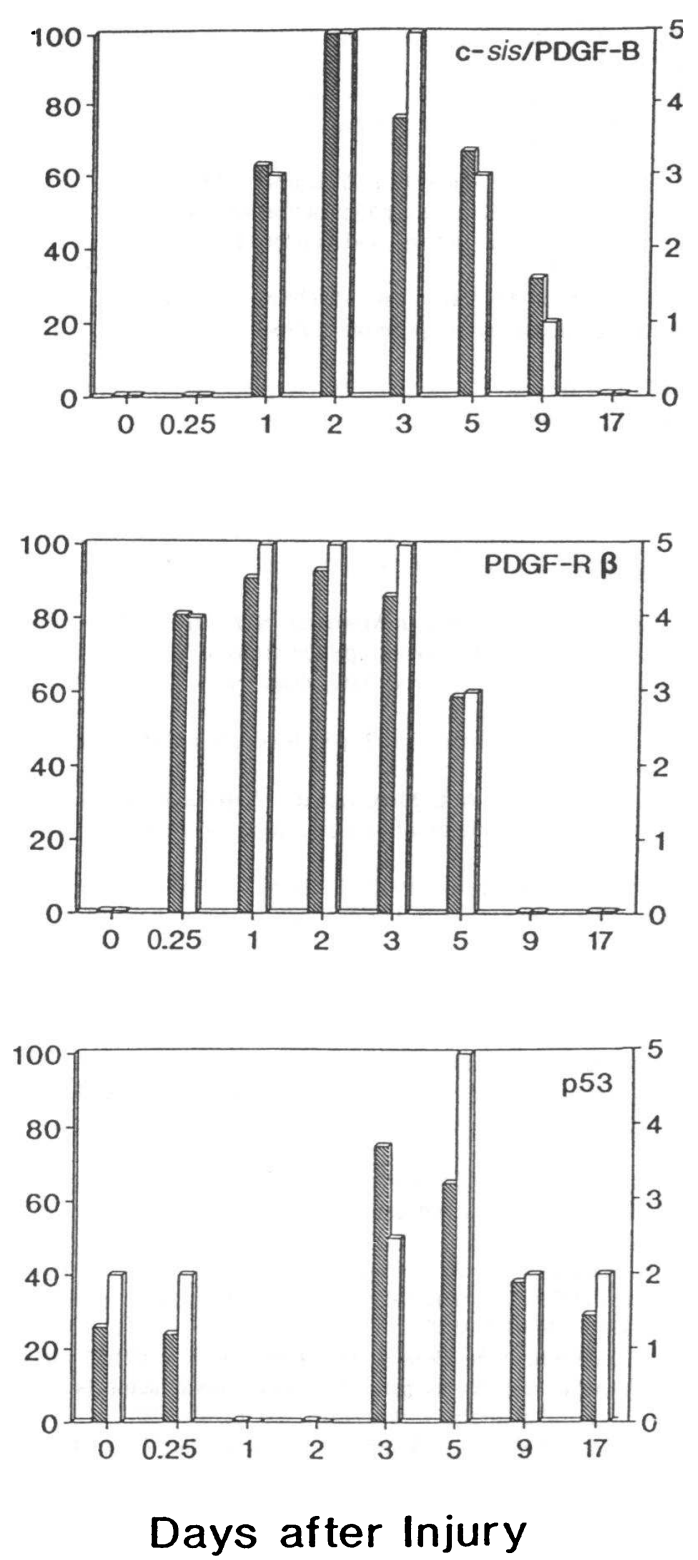

Figure 7. Comparison of the time course of expression of p53 mRNA and protein product to that of $\mathrm{c}-$ sis/PDGF-B and PDGF-R $\beta$ during the course of tissue regeneration. Notice the inverse relationship between the expression of $\mathrm{p} 53$ and that of PDGF-B and PDGF-R $\beta .-$, Percentage of cells expressing mRNA; $\square$, protein expression.

In contrast, as shown here, the $\mathrm{p} 53$ protein expression was totally suppressed during the phase of active cellular proliferation after injury, and it reemerged during the period of the healing process (Fig. 4). The expression of p53 protein reached a peak on about day 5 after injury, which coincides with the time of epithelialization of the injured tissue in this in vivo model (41). The suppression of $\mathrm{p} 53$ during the active proliferative state is consistent with the antiproliferative role, attributed to wild type p53 protein (15-21). Its suppression during this stage of proliferation after injury serves to remove an agent involved in negative cell growth. On the other hand, its strong expression at the time of epithelialization and healing may serve to downregulate the proliferative process. This is consistent with the finding that overexpression of wild type p53 in- hibits cell proliferation by blocking the cells in the G1 phase of the cell cycle $(16,19)$.

It is apparent from the present data that during tissue regeneration, there is an inverse relationship between $\mathrm{p} 53$ expression and that of the c-sis/PDGF-B mitogen and its receptor (Fig. 7). This inverse relationship between growth-promoting and growth-arresting factors suggests the presence of well-controlled in vivo mechanisms that regulate the physiologic processes of normal tissue regeneration. In pathologic proliferative disorders, there seems to be a disruption of this well-controlled balance between mitogenic growth factors that promote cellular proliferation and suppressor genes that contribute to the arrest of cellular proliferation. There is strong evidence that the restraining function of wild type p53 protein is removed in malignancies through mutation-inactivation of the functional p53 protein $(36,38,42,50-54)$. In these pathologic cases, the uncontrolled expression of mitogenic growth factors coupled with the inactivation of $\mathrm{p} 53$ protein will favor uncontrolled, pathologic cellular proliferation.

Wild-type P53 protein is a transcriptional transactivator (22-30) and also a transcriptional suppressor of several genes (31-35), including c-fos $(31,33)$ and c-jun (31). The presence of the TATA element in the promoter region of genes appears to be necessary for their suppression by the wild type $\mathrm{p} 53$ protein (35). In the present studies, there is no evidence that $\mathrm{p} 53$ participates in the induction of the expression of c-sis/PDGF-B and PDGF-R $\beta$ mRNAs after injury. As shown above, during the induction of the expression of these genes, the levels of p53 protein remained either unchanged ( $6 \mathrm{~h}$ after injury) or were totally suppressed (days 1 and 2 after injury). On the other hand, it is possible that $\mathrm{p} 53$ protein contributes to the suppression of these genes during the healing process. At this stage, the p53 protein levels increased, while the c-sis/PDGF-B and PDGF-R $\beta$ levels kept declining and were totally suppressed upon the complete healing of the wound (Fig. 7). Since there is no identifiable TATA element in c-sis/PDGF-B or PDGF-R b, it is conceivable that suppression of these genes by $\mathrm{p} 53$ in vivo, may involve indirect transcriptional transactivation of other genes, which in turn induces the suppression of the mitogenic genes.

In conclusion, normal tissue regeneration after injury includes the following molecular mechanisms: (a) selective localized expression of mitogenic growth factors that promote cell proliferation; (b) concomitant suppression of p53 which inhibits cell proliferation; $(c)$ suppression of the mitogenic growth factors upon healing of the injured tissue; and $(d)$ strong expression of $\mathrm{p} 53$, which serves to downregulate cellular growth during the stages of healing.

\section{Acknowledgments}

The authors wish to thank Bert Vogelstein for the provision of human p53 cDNA Tucker Collins for the human c-sis/PDGF-B cDNA and Axel Ullrich for the murine PDGF-R $\beta$ cDNA. We thank Shirley Lerner Nicholson for preparation of the manuscript.

This research was supported by National Institutes of Health Grant CA30101, by the Council for Tobacco Research, USA, Inc., and by the Institute of Molecular Biology.

\section{References}

1. Jennishce, E., A. Skottnes, and H.-A. Hansson. 1987. Dynamic changes of insulin-like growth factor I immunoreactivity correlate to repair events in rat ear after freeze-thaw injury. Exp. Mol. Pathol. 47:193-201. 
2. Hansson, H.-A., E. Jennische, and A. Skottner. 1987. Regenerating endothelial cell express insulin-like growth factor I immunoreactivity after arterial injury. Cell Tissue Res. 250:499-505.

3. Hansson, H.-A., R. Jonsson, and K. Petruson. 1988. Transiently increased insulin-like growth factor I. Immunoreactivity in UVB-irradiated mouse skin. $J$. Invest. Dermatol. 91:328-332.

4. Grotendorst, G. R., C. A. Grotendorst, and T. Gilman. 1988. Production of growth factors (PDGF and TGF-beta) at the site of tissue repair. Prog. Clin. Biol. Res. 266:47-54.

5. Grotendorst, G. R., Y. Soma, K. Takehara, and M. Charette. 1989. EGF and TGF-alpha are potent chemoattractants for endothelial cells and EGF-like peptides are present at sites of tissue regeneration. J. Cell. Physiol. 139:617-623.

6. Steefnos, H., C. Lossing, and H. A. Hansson. 1990. Immunohistochemical demonstration of endogenous growth factors in wound healing. Wounds. 2:218 226.

7. Golden, M. A., Y. P. Au, R. D. Kenegy, and A. W. Clowes. 1990. Growth factor gene expression by intimal cells in healing polytetrafluorethylene grafts. $J$. Vasc. Surg. 11:580-585.

8. Kane, C. J. M., P. C. Hanawait, A. M. Knapp, and J. N. Mansbridge. 1990 Transforming growth factor- $\beta 1$ localization in normal and psoriatic epidermal keratinocytes in situ. J. Cell. Physiol. 144:144-150.

9. Whitby, D. J., and M. W. Ferguson. 1991. Immuno-histochemical localization of growth factors in fetal wound healing. Dev. Biol. 147:207-215.

10. Antoniades, H. N., T. Galanopoulos, J. Neville-Golden, C. P. Kiritsy, and S. E. Lynch. 1991. Injury induces in vivo expression of PDGF and PDGF-receptor mRNAs in skin epithelial cells and PDGF mRNA in connective tissue fibroblasts. Proc. Natl. Acad. Sci. USA. 88:565-569.

11. Werner, S., K. G. Peters, M. T. Longaker, F. Fuller-Pace, M. J. Bander, and L. T. Williams. 1992. Large induction of keratinocyte growth factor expression in the dermis during wound healing. Proc. Natl. Acad. Sci. USA. 89:6896-900.

12. Antoniades, H. N., T. Galanopoulos, J. Neville-Golden, C. P. Kiritsy, and S. E. Lynch. 1993. Expression of growth factor and receptor mRNAs in skin epithelial cells following acute cutaneous injury. Am. J. Pathol. 142:1099-1110.

13. Antoniades, H. N. 1991. PDGF: a multifunctional growth factor. Bailliere's Clin. Endocrin. Metabol. 5:595-613.

14. Matlashewski, G., P. Lamb, D. Pim, J. Peacock, L. Crawford, and S. Benchimol. 1984. Isolation and characterization of a human p53 cDNA clone: expression of the human p53 gene. EMBO (Eur. Mol. Biol. Organ.) J. 3:3257-3262.

15. Diller, L., J. Kassel, C. E. Nelson, M. A. Greyka, G. Litwak, M. Behbardt, B. Bressac, M. Ozturk, S. J. Baker, B. Volgestein, and S. H. Friend. 1990. p53 functions as a cell cycle control protein in osteosarcoma. Mol. Cell. Biol. 10:5772-5781.

16. Mercer, W. E., M. T. Shields, M. Amin, G. J. Sauve, E. Apella, J. W. Romano, and S. J. Ullrich. 1990 . Negative growth regulation in a glioblastoma tumor cell line that conditionally expresses human wild-type p53. Proc. Natl. Acad. Sci. USA. 87:6166-6170.

17. Michalovitz, D., O. Halevy, and M. Oren. 1990. Conditional inhibition of transformation and of cell proliferation by a temperature-sensitive mutant of p53. Cell. 62:671-680.

18. Martinez, J., I. Georgoff, J. Martinez, and A. J. Levine. 1991. Cellular localization and cell cycle regulation by a temperature-sensitive p53 protein. Genes \& Dev. 5:151-159.

19. Mercer, W. E., M. T. Shields, D. Lin, E. Appella, and S. J. Ullrich. 1991 Growth suppression induced by wild-type p 53 protein is accompanied by selective down-regulation of proliferating-cell antigen expression. Proc. Natl. Acad. Sci. USA. 88:1958-1962.

20. Ginsberg, D., D. Michael-Michalovitz, D. Ginsberg, and M. Oren. 1991 Induction of growth arrest by a temperature-sensitive p53 mutant is correlated with increased nuclear localization and decreased stability of the protein. $\mathrm{Mol}$. Cell. Biol. 11:582-585.

21. Lin, D., M. Shields, S. Ullrich, E. Apella, and W. Mercer. 1992. Growth arrest induced by wild-type $\mathrm{p} 53$ protein blocks cells prior to or near the restriction point in late $G_{1}$ phase. Proc. Natl. Acad. Sci. USA. 89:9210-9214.

22. Fields, S., and S. K. Jang. 1990. Presence of a potent transcription activating sequence in the p53 protein. Science (Wash. DC). 249:1046-1049.

23. Raycroft, L., H. Wu, and G. Lozano. 1990. Transcriptional activation by wild-type but not transforming mutants of the p53 anti-oncogene. Science (Wash. DC). 249:1049-1051.

24. Kern, S. E., K. W. Kinzler, A. Bruskin, D. Jarosz, P. Friedman, C. Prives and B. Vogelstein. 1991. Identification of p53 as a sequence-specific DNA-binding protein. Science (Wash. DC). 252:1708-1711.

25. Bargonetti, J., P. N. Friedman, S. E. Kern, B. Vogelstein, and C. Prives 1991. Wild-type but not mutant p53 immunopurified proteins bind to sequences adjacent to the SV40 origin of replication. Cell. 65:1083-1091.

26. Zambetti, G. P., J. Bargonetti, K. Walker, C. Prives, and A. J. Levine. 1992 Wild-type p53 mediates positive regulation of gene expression through a specific DNA sequence element. Genes \& Dev. 6:1143-1152.

27. Farmer, G., J. Bargonetti, H. Zhu, P. Friedman, R. Prywes, and C. Prives. 1992. Wild-type p53 activates transcription in vitro. Nature (Lond.). 358:83-86 28. Funk, W. D., D. J. Pak, R. H. Karas, W. E. Wright, and J. W. Shay. 1992. A transcriptionally active DNA binding site for human p53 protein complexes. Mol. Cell. Biol. 12:2866-2871.

29. Reed, M., Y. Wang, G. Mayr, M. E. Anderson, J. F. Schwedes, and P. Tegtmeyer. 1992. p53 domains: suppression, transformation, and transactivation. Gene Expression. 3:95-107.

30. Unger, T., J. A. Mietz, M. Scheffner, C. L. Yee, and P. M. Howley. 1993. Functional domains of wild-type and mutant $\mathrm{p} 53$ proteins involved in transcriptional regulation, transdominant inhibition, and transformation suppression Mol. Cell. Biol. 13:5186-5194.

31. Ginsberg, D., F. Mechtor, M. Yaniv, and M. Oren. 1991. Wild-type p53 can down-modulate the activity of various promoters. Proc. Natl. Acad. Sci. USA 88:9979-9983.

32. Santhanam, M., A. Ray, and P. B. Sehgal. 1991. Repression of the interleukin 6-gene promoter by $\mathrm{p} 53$ and the retinoblastoma susceptibility gene product. Proc. Natl. Acad. Sci. USA. 88:7605-7609.

33. Kley, N., R. Chung, S. Ray, J. Loeffler, and B. Seizinger. 1992. Repression of the basel c-fos promoter by wild-type p53. Nucleic Acid Res. 20:4083-4087.

34. Kern, S., J. A. Pietenpol, S. Thiagalingam, A. Seymour, K. Kinsler, and B. Vogelstein. 1992. Oncogenic forms of $\mathrm{p} 53$ inhibit p53-regulated gene expression. Science (Wash. DC). 256:827-832.

35. Seto, E., A. Usheva, G. P. Zambetti, J. Momand, N. Horikoshi, R. Weinmann, A. J., Levine, and T. Shenk. 1992. Wild-type p53 binds to the TATA-binding protein and represses transcription. Proc. Natl. Acad. Sci. USA. 89:1202812032.

36. Vogelstein, B., and K. W. Kinzler. 1992. p53 function and dysfunction. Cell. 70:523-526.

37. Ullrich, S. J., C. W. Anderson, W. E. Mercer, and E. Appella. 1992. The p53 tumor suppressor protein, a modulator of cell proliferation. J. Biol. Chem. 267:15259-15262.

38. Zambetti, G. P., and A. J. Levine. 1993. A comparison of the biological activities of wild-type and mutant p53. FASEB (Fed. Am. Soc. Exp. Biol.) J. 7:855-865.

39. Kastan, M. B., O. Onyekwere, D. Sidransky, B. Vogelstein, and R. W. Craig. 1991. Participation of 553 protein in the cellular response to DNA damage. Cancer Res. 51:6304-6311.

40. Kastan, M. B., Q. Zhan, W. S. El-Deiry, F. Carrier, T. Jacks, W. V. Walsh, B. S. Plunkett, B. Vogelstein, and A. J. Fornace, Jr. 1992. A mammalian cell cycle checkpoint pathway utilizing p53 and GADD45 is defective in ataxia-telangiectasia. Cell. 71:587-597.

41. Lynch, S. E., R. B. Colvin, and H. N. Antoniades. 1989. Growth factors in wound healing: single and synergistic effects on partial thickness porcine skin wounds. J. Clin. Invest. 84:640-646.

42. Baker, S. J., S. Markowitz, E. R. Fearon, J. K. V. Willson, and B. Vogelstein. 1990. Suppression of human colorectal carcinoma cell growth by wild-type p53. Science (Wash. DC). 249:912-915.

43. Collins, T., D. Ginsburg, J. M. Boss, S. H. Orkin, and J. S. Pober. 1985. Cultured human endothelial cells express platelet-derived growth factor $\beta$-chain: cDNA cloning and structural analysis. Nature (Lond.). 316:748-750.

44. Yarden, Y., J. A. Escobedo, W. J. Kuang, T. L. Yang-Feng, T. O. Daniel, P. M. Tremble, E. Y. Chen, H. E. Ando, R. N. Harkins, V. Francke, et al. 1986. Structure of the receptor for platelet-derived growth factor helps define a family of closely related growth factor receptors. Nature (Lond.). 323:226-232.

45. Höfler, H., H. Childers, M. R. Monminy, R. M. Lechan, R. H. Goodman, and H. J. Wolfe. 1986. In situ hybridization methods for the detection of somatostatin mRNA in tissue sections using antisense RNA probes. Histochem. J. 18:597-604

46. Danscher, G., and J. Noregaard. 1983. Light microscopic visualization of colloidal gold on resin embedded tissue. J. Histochem. Cytochem. 31:1394-1398.

47. Yewdell, J., J. V. Gannon, and D. P. Lane. 1986. Monoclonal antibody analysis of p53 expression in normal and transformed cells. J. Virol. 59:444-452.

48. Milner, J., A. Cook, and M. Sheldon. 1987. A new anti-p53 monoclonal antibody, previously reported to be directed against the large $\mathrm{T}$ antigen on Simian virus 40. Oncogene. 1:453-455.

49. Key, G., M. H. Becker, B. Baron, and M. Duchrow. 1992. New Ki-67-equivalent murine monoclonal antibodies (MIB 1-3) generated against bacterially expressed parts of the $\mathrm{Ki}-67 \mathrm{cDNA}$ containing three 62 base pair repetitive elements encoding for the $\mathrm{Ki}-67$ epitope. Lab. Invest. 68:629-636.

50. Finlay, C. A., P. W. Hinds, and A. J. Levine. 1989. The p53 proto-oncogene can act as a suppressor of transformation. Cell. 57:1083-1093.

51. Baker, S. J., E. R. Fearon, J. M. Nigro, S. R. Hamilton, A. C. Preisinger, J. M. Jessup, P. van Tuinen, D. H. Ledbetter, D. F. Barker, Y. Nakamura, et al. 1989. Chromosome 17 deletions and p53 gene mutations in colorectal carcinomas. Science (Wash. DC). 244:217-221.

52. Hollstein, M., D. Sidransky, B. Vogelstein,and C. C. Harris. 1991. p53 mutations in human cancers. Science (Wash. DC). 253:49-53.

53. Levine, A. J., J. Momand, and C. A. Finlay. 1991. The p53 tumor suppressor gene. Nature (Lond.). 351:453-456

54. Unger, T., M. N. Nau, S. Segal, and J. D. Minna. 1992. p53: A transdominant regulator of transcription whose function is ablated by mutations occurring in human cancer. EMBO (Eur. Mol. Biol. Organ.) J. 11:1383-1390. 